\title{
STRATEGI PENGEMBANGAN DESAIN KRIYA (RAGAM HIAS) DALAM PERSPEKTIF POTENSI LOKALITAS
}

\author{
Eko Haryanto *)
}

\begin{abstract}
ABSTRACK
This research is to obtain a description of the locality paradigm, strategies and the factors that influence the development of decorative potential in perspective locality made by artisans craft to face the globalization. Expected outcomes produces a theoretical foundation for reading a variety of economic opportunities craft and model form of product design, especially in the decorative craft yet still economically behavior characterized by locality. This becomes relevant because the decorative craft art is as a carrier in addition to the values of life as well as national identity in order to resist globalization.

The research approach is qualitative descriptive explanatory once. The design used was a multi intrinsic case. Subjects were centers of craft in Jepara carving, batik in Pekalongan, and brass at the Heilbron Pati. The technique consists of data collection interview, observation, and documentation. The data analysis was guided by theoretical propositions and developing a description. In particular, the analysis uses a combination of domain analysis and analytical explanations are framed with data reduction procedures, data analysis and conclusion.

Based on the results of the study concluded craft artisans to design paradigm locality in the very nature of globalization is flexible or dynamic. Model development strategy decorative is done intrinsically and extrinsically, imitate the decorative ngetrend, and create decorative based research. Factors influencing craftsmen design development strategies are internal and external factors. It is suggested that craftsmen need to continuously create the development of unigue decoration from the immediate environment of inspiration and artisans, designers, academics, policy actors should coordinate the development of a variety of localities that can penetrate globalization.
\end{abstract}

\section{ABSTRAK}

Peneilitian ini untuk memperoleh penjelasan mengenai paradigma lokalitas, strategi dan faktor-faktor yang berpengaruh dalam pengembangan ragam hias dalam perspektif potensi lokalitas yang dilakukan oleh pengrajin kriya dalam menghadapi globalisasi. Luaran yang diharapkan adalah dihasilkan sebuah landasan teoritik untuk membaca berbagai peluang ekonomis kriya sekaligus model desain bentuk produk khususnya ragam hias pada kriya yang tetap laku secara ekonomis namun bercirikan lokalitas. Hal ini menjadi relevan karena ragam hias pada seni kriya di samping sebagai pembawa nilai-nilai kehidupan sekaligus sebagai identitas kebangsaan dalam rangka menahan globalisasi.

* Eko Haryanto, Dosen Jurusan Seni Rupa Universitas Negeri Semarang 
Pendekatan penelitian adalah kualitatif deskriptif sekaligus eksplanatoris. Desain yang digunakan adalah multi kasus intrinsik. Subjek penelitian adalah sentra kriya ukir di Jepara, batik di Pekalongan, dan kuningan di Juwana Pati. Teknik pengumpulan data terdiri wawancara, observasi, dan dokumentasi. Teknik analisa data masih berpedoman proposisi teoritik dan pengembangan deskripsi. Secara khusus analisisnya menggunakan kombinasi analisis domain dan analisis eksplanasi yang dikerangkai dengan prosedur reduksi data, analisa data dan penarikan kesimpulan.

Berdasarkan hasil penelitian disimpulkan paradigma pengrajin kriya terhadap desain lokalitas dalam globalisasi adalah sangat bersifat fleksible atau dinamis. Model strategi pengembangan ragam hias dilakukan secara intrinsik dan ekstrinsik, meniru ragam hias yang lagi ngetrend, dan menciptakan ragam hias berdasarkan riset. Faktor-faktor yang mempengaruhi pengrajin strategi pengembangan desain adalah faktor internal dan eksternal. Saran yang dapat dikemukakan pengrajin perlu menciptakan ragam hias yang unigue dengan terus mengembangkan dari inspirasi yang lingkungan terdekat dan perajin, desainer, akademisi, pelaku kebijakan sebaiknya berkoordinasi dalam pengembangan ragam lokalitas yang mampu menembus globalisasi.

Kata Kunci: Strategi, Batik, Ukir, Kuningan, dan Ragam Hias

\section{PENDAHULUAN}

Jepara dikenal sebagai kota kriya ukir karena sentra kriya terapan yaitu mebel dan kriya seni berupa ukiran-ukiran kayu yang hampir tersebar merata di seluruh kecamatan. Kriya batik pekalongan juga merupakan aset atau khasanah kriya khas Indonesia yang merepresentasikan daerah dengan kultur pesisiran. Batik merupakan produk yang menawarkan segi kekriyaan sekaligus fungsional. Aspek kekriyaan dengan ketrampilan tangan yang tinggi dalam prosesnya telah diyakini menjadi salah satu kekuatannya. Tidak berbeda dengan seni ukir dan batik. Kriya kuningan di daerah Juwana Pati juga menunjukkan produk-produk yang rumit dan indah. Prosesnya yang melibatkan desain-desain ornamen khas indonesia dan dibuat tangan juga menjadikan sebuah kriya yang sangat penting bagi masyarakat.
Namun, sayangnya berbagai produk kuningan yang ada di pasaran sekarang sedikit demi sedikit apresiasi penggunaannya telah menurun. Oleh sebab itu, keberadaannya yang semula kebanyakan kriya seni telah berubah menuju kriya fungsional. Kekhasan ornamen atau ragam hias yang selalu menyertai aspek produknya menjadi terkikis.

Hal tersebut sedikit banyak juga berimbas pada kriya ukir dan batik. Bedanya ragam hias pada kriya ukir dan batik sangat berkembang karena tuntutan masyarakat akan kriya tersebut sangat tinggi terutama pada kriya batik. Dalam era sekarang, mulainya ada fenomena estetika yang dijadikan sebagai standar produksi adalah estetika praktis. Biaya produksi yang lebih murah turut menentukan orientasi akhir bentuk penciptaan. 
Seniman atau kriyawan, dalam hal ini terkadang asal comot tanpa memahami konteks penciptaan dan pemaknaan simbol terlebih dahulu. Strategi berkarya tersebut dapat semakin menambah alienasi masyarakat akan nilai-nilai esensial produknya. Eksistensi produk kriya akhirnya juga semakin menunjukkan ketidakberdayaannya sebagai pembawa nilai-nilai normatif, falsafah hidup, dan pedoman. Akhirnya, komunitas merasa tidak memiliki, apalagi untuk menghayati dan mengejawantahkannya (Rosyada, 2007: 65).

Atas dasar tersebut, fenomena kriya khususnya ukir, batik, dan kuningan menarik untuk dijadikan subjek penelitian. Sebuah desain kriya tidak mungkin berdiri secara absolut tanpa terpengaruh aspek lain. Oleh karena itu, secara spesifik kajian ini tidak hanya difokuskan pada kajian estetik semata tetapi akan dikaitkan aspek ekonomi, sosial, politik, dan budaya. Keberadaannya dapat sebagai faktor pendukung sekaligus konteks estetik. Dengan demikian, pendekatan yang digunakan lebih bersifat holistik dan integral dengan melibatkan berbagai aspek yang berpengaruh terhadap estetika produk kriya.

Secara lebih khusus, permasalahan menarik yang ingin diungkap adalah paradigma pengrajin terhadap desain lokalitas dalam konteks globalisasi. Mengetahui model atau strategi pengembangan desain khususnya pada ragam hias yang dilakukan pengrajin terhadap perkembangan globalisasi dan faktor-faktor yang mempengaruhi para pengrajin melakukan strategi pengembangan desain khususnya pada ragam hias pada ukir, batik, dan kuningan. Harapan yang ingin diperoleh, secara teoritik, diperolehnya landasan konseptual dalam pengembangan desain kriya sehingga pengrajin kriya dapat mengembangkan kriya ukir, batik, dan kuningan yang lebih diterima pasar dengan tetap memberikan corak identitas kelokalan.

\section{METODE}

Pendekatan penelitian adalah deskriptif kualitatif sekaligus eksplanatoris. Desain penelitian adalah studi kasus intrinsik dengan jenis multi kasus holistik. Subjek penelitian adalah kriya ukir Jepara, kriya kuningan Juwana Pati, dan kriya batik Pekalongan. Sasaran penelitian adalah paradigma perajin terhadap lokalitas dalam globalisasi, pola pengembangan desain kriya khususnya pada ragam hias dan faktor-faktor yang mempengaruhi bentuk desain ragam hiasnya. Sumber data primer adalah pengrajin, produk desain, masyarakat dan dinas terkait. Sumber data sekunder adalah berupa buku-buku dan dokumen yang berkenaan dengan seni kriya tersebut.

Teknik pengumpulan data menggunakan wawancara, observasi, dan dokumentasi. Analisis data masih berpedoman proposisi teoritik dan pengembangan deskripsi. Tahapan analisis diawali reduksi data, sajian data, dan penarikan kesimpulan. Triangulasi data dilakukan untuk membandingkan dan mengecek tingkat derajat kepercayaan atas data yang telah terpilih baik dari sumber, metode, dan alat pengumpul data yang berbeda-beda agar keabsahan data terjaga. Selanjutnya, dilakukan diskusi dengan 
teman sejawat atau ahli yang berkompeten terhadap kriya.

\section{PEMBAHASAN}

1. Identifikasi Kondisi Geografi dan Demografi Wilayah Pengkajian

Jepara sebagai salah satu Kabupaten di Jawa Tengah yang berlokasi di daerah pesisir dan terkenal sebagai kota ukir karena terdapat sentra kerajinan ukiran kayu. Industri tersebut telah menjadi tulang punggung perekonomian bagi penduduk Jepara. Kerajinan mebel dan ukir ini tersebar merata hampir di seluruh kecamatan dengan karakteristik produk masing-masing.

Kabupaten Pekalongan merupakan perpaduan antara wilayah datar di bagian utara dan sebagian wilayah dataran tinggi di bagian selatan. Penduduk Kabupaten Pekalongan pada akhir tahun 2011 tercatat sebanyak 848.710 jiwa yang bekerja dalam industri batik. Selain batik, masyarakat juga memproduksi kerajinan batok kelapa, tempurung kelapa yang dibuat kerajinan tas, kancing dsb. Di sampuing itu masyarakat memiliki budaya tradisional seperti Upacara Tradisi Syawalan Kesenian Kuda Kepang.

Kota Juwana merupakan kota di pesisir utara pulau Jawa yang menghubungkan kota Pati dan kota Rembang. Kota Juwana merupakan kota terbesar kedua di Kabupaten Pati setelah Pati. Juwana memiliki luas 55,93 kilometer persegi. Kecamatan Juwana terdiri atas 29 desa. Mayoritas penduduk kecamatan Juwana bermatapencarian sebagai petani, nelayan dan buruh. Ciri khas kecamatan Juwana adalah usaha kerajinan logam kuningan yang sebagian besar terdapat di desa Growonglor dan sekitarnya, serta usaha tambak perikanan atau pembudidayaan bandeng di desa Bajomulyo, Agungmulyo dan desa-desa sekitarnya. Dua perusahaan kuningan terbesar dari kota Juwana adalah Krisna \& Sampurna.

\section{Sekilas Proses Pembuatan Seni Kriya}

Berikut ini langkah-langkah proses pembuatan ukir dimulai (1) memindahkan desain pada kertas tipis pada kayu, (2) Gethaki, yaitu memahat gambar pola sehingga menembus bidang kayu, (3) Malesi, yaitu melebarkan garis-garis pahatan sehingga batas pinggir dan arah gambar yang diukir kelihatan, (4) Dasari, yaitu membuat dasar dasaran ukir sehingga lebih rendah daripada pola ukirnya, (5) Grabahi yaitu membentuk secara penuh sesuai yang dikehendaki, (6) Matut, yaitu menyempurnakan bentukbentuk grabahai menjadi ukiran jadi, (7) Benangi, yaitu membuat garis-garis setebal benang sebagai gambar tulang daun, (8) Mecahi, yaitu membuat sobekan-sobekan daun dan urat daun, dan (9) Ngelus yaitu menghaluskan seluruh ukiran dengan amplas.

Batik dibuat di atas kain putih yang sudah siap. Kemudian disket, diklowongi, ditemboki yaitu mengisi motif batik yang sudah diklowong dengan motif-motif tertentu dengan malam, baik berupa titiktitik, garis-garis maupun blok. Setelah itu diterusi yaitu membatik di sebaliknya kain pada bekas tembusnya. Tahap selanjutnya adalah pewarnaan dengan cara medel maupun soga. Selanjutnya adalah pelorodan yaitu menghilangkan lilin dengan cara memasukkan kain batik ke 
dalam air yang mendidih. Terakhir, adalah pembersihan dan pengeringan.

Pertama dalam proses produksi kuningan adalah pembuatan cetakan. Cetakan ada dua macam yaitu cetakan basah yang dibuat dari silikon dan hanya dipakai dalam satu kali cetak. Cetakan kedua yaitu cetakan press yang dibuat dari alumunium dan timah lembek. Kemudian adalah peleburan bahan-bahan. Dalam peleburan yang perlu disiapkan adalah tangki berisi minyak tanah $3 / 4$ nya sedang $1 / 4$ dipersiapkan diisi udara, kompor, selang, tengku peleburan yang sudah diisi kowi, ciduk, tang besar. Bahan-bahan dibakar sampai mencair selama sekitar 5 jam. Kemudian cetakan-cetakan dituangi cairan kuningan atau dicor. Setelah beberapa menit, cetakan dibuka, dibongkar, dihilangkan bagian-bagian yang tidak dikehendaki dengan kikir atau gergaji. Terakhir, permukaaan diratakan dan diselep agar mengkilap. Setelah itu dilakukan pencucian, penawaran, pelapisan atau coating.

3. Perkembangan Ragam Hias Seni Kriya dari Awal Sampai Sekarang

Kriya terbagi menjadi kriya terapan dan kriya seni. Terapan memiliki nilai praktis karena benda terap dapat dipergunakan untuk keperluan praktis sehari-hari. Kriya seni adalah disamping bersifat fungsional tetapi nilai keindahan lebih diutamakan. Nilai keindahan ragam hias pada awalnya diciptakan dengan maksud religius. Berdasarkan Haryanto (2004) dapat diuraikan pegeseran ataupun perubahan fungsi ragam hias dalam kriya ukir di Jepara mulai dari hiasan, simbolisme, aktualisasi diri. Sebagai hiasan, keberadaan ragam hias sebagai hiasan memiliki tujuan untuk meningkatkan nilai estetis produk ukir. Sebagai simbolisme, ragam hias lebih mengutamakan isi atau pemaknaan daripada keindahan visualnya. Pada masyarakat sekarang, kehadiran sebuah ragam hias dapat dipandang sebagai bentuk aktualisasi diri. Hal tersebut hanya upaya untuk menunjukkan atau membangun citra diri dari pada hal-hal yang bersifat aktual. Sekarang ini, berkembang pula gaya ragam hias polos atau minimalis dengan semboyan form Follow Function sebagai azab atau mainstream gaya modern. Gaya klasik, modern, dan posmodern hidup berdampingan. Kriya ukir di Jepara juga memiliki dimensi nilai yang realistik, ekspresif, formalistik, dan simbolistik.

Batik Pekalongan memiliki motif yang bersifat naturalistik, komposisi warna kaya, bernuansa pesisir. Ragam hias batik juga dipengaruhi oleh berbagai pengaruh asing seperti Tionghoa dan Eropa. Berbagai unsur-unsur motif batik yaitu motif pokok, motif pendukung, dan isenisen yang saling berkaitan dan bersatu. Dalam perkembangannya, batik dapat digolongkan menjadi dua macam, yaitu: batik tradisional, batik modern atau batik kreasi baru. Batik tradisional yaitu susunan motifnya terikat oleh suatu ikatan tertentu dengan isen-isen tertentu. Batik modern atau kreasi baru, yaitu semua macam jenis batik yang motif dan gayanya tidak seperti batik tradisional. Ada beberapa jenis gaya dalam batik modern atau kreasi baru antara lain, gaya abstrak, gabungan, lukisan, dan gaya khusus dari cerita lama atau juga pembuatan batik dengan "proses lukisan". Pada era pasar, hampir semua 
motif itu tetap laku di pasaran. Begitu pula sebaran sebuah motif yang telah menjadi identitas sebuah daerah sekarang mulai menyebar lintas regional dan daerah.

Sedangkan corak ragam hias kuningan dari awal berkembang sampai saat ini bisa dibilang cukup stagnan. Penyebabnya adalah masyarakat sudah menemukan kriya pengganti dengan bahan-bahan yang lebih murah dan desain yang lebih up to date. Ragam hias yang hadir disamping berfungsi sebagai hiasan terdapat pula yang berfungsi konstruktif. Keberadaan ragam hias pada kriya kuningan dengan demikian jumlahnya tidak sevariatif dan sebebas kriya ukir maupun batik. Di kuningan ini, ragam hias lebih banyak berupa stilasi tumbuh-tumbuhan yang dibuat secara berulang-ulang baik secara repetitif, flowing, alternatif, maupun progresif.

4. Paradigma Pengrajin Kriya Terhadap Desain Ragam Hias Lokalitas dalam Konteks Globalisasi

Berdasarkan data-data yang diperoleh menunjukkan bahwa setiap pengrajin dalam hal ini adalah para pengusaha yang memiliki usaha kriya batik, usaha kriya kuningan dan kriya ukir memiliki cara pandang yang berbeda-beda dalam memaknai tentang lokalitas. Lokalitas lebih bersifat pragmatis, lebih manual, adanya campuran antar motif. Baginya, pragmatis adalah desain lokalitas yang mampu mencerminkan budaya lokal namun harus dapat diterima pasar. Manual adalah metode berkarya yang menggunakan tangan manual atau dengan batik tulis bukan dengan printing di situlah esensi lokalitas. Tentu saja aspek ragam hias tetap diperhitungkan meskipun bukan yang paling ditekankan. Meskipun beberapa pengrajin memaknai lokalitas berdasarkan bentuk ragam hias yang tervisualkan pada kain batik haruslah asli dari Pekalongan. Terakhir, lokalitas tidak harus menampilkan corak ragam hias yang hanya tradisional tanpa adanya modifikasi corak ragam hias dari daerah lainnya sehingga bentuknya akhirnya berupa perpaduan antar daerah.

Lokalitas menurut pengrajin Jepara telah dimaknai secara tegas dan jelas. Lokalitas adalah dapat teraplikasikannya desain sulur-suluran atan flora dalam setiap karya produk yang diciptakan. Namun demikian, pengrajin Jepara sadar lokalitas tidak harus diaplikasikan secara seratus persen. Lokalitas sebaiknya dapat menyesuaikan perkembangan globalisasi secara fleksible. Lokalitas harus bisa disandingkan ragam hias dari daerah lain maupun dari Barat.

Sedangkan, berdasarkan pengrajin

kriya kuningan, lokalitas lebih menunjukkan dimensi pluralitas Nusantara. Bukan menunjukan sebuah ragam hias yang semata-mata berasal dari daerah Juwana Pati tersebut saja. Namun, jika ditarik secara lebih jauh dan menyeluruh paradigma lokalitas menurut para pengrajin kriya ukir, batik dan kuningan, lokalitas pada prinsipnya lebih dimaknai sebagai bagian dari strategi agar penjualan produknya meningkat. Pemahaman mengenai ragam hias lokalitas dalam konteks globalisasi yang bervariatif disebabkan oleh beberapa hal yaitu pengrajin jarang menambah wacana referensi perkembangan seni dan desain secara lebih komprehensif. Perlombaan 
kriya dengan desain kurang terespon pelaku kriya di tingkat pengrajin kecil.

\section{Model Strategi Pengembangan Ragam} Hias dalam Melakukan Adaptasi Terhadap Perkembangan Globalisasi

Berikut ini adalah beberapa model atau strategi pengembangan ragam hias yang dilakukan oleh pengrajin dalam beradaptasi terhadap perkembangan globalisasi.

Model Pengembangan Ragam Hias secara Intrinsik. Strategi ini adalah lebih mengedepankan bagaimana ragam hias yang tercipta tersebut distilasi, ditransformasi, didistorsi maupun dideformasi pada unsur-unsur rupa ragam hias tersebut agar mampu menampilkan gaya yang lebih indah. Ragam hias didesain dengan mempertimbangkan prinsip formalistik yaitu kesederhanaan, keselarasan, irama, kesatuan, keharmonisan yang terpadu menjadi satu kesatuan produk yang indah estetik, dan fungsional, serta mampu mencerminakan nilai rasa atau taste secara ekslusif.

Model kedua adalah mencoba mengembangkan ragam hias dengan kekuatan ekstrinsik yaitu nilai makna atau simbolis. Model kedua ini lebih mengedepankan makna atau nilai simbolis sebagai variabel utama dalam penciptaan sebuah ragam hias. Model ketiga adalah mencoba meniru karya yang lagi ngetrend. Dalam rangka menyesuaikan dinamika pasar maka perajin terkadang mengembangkan ragam hias dengan mengadopsi bentuk-bentuk yang lagi ngetrend di pasar tanpa mengkaitkan atau mengkorelasikan dengan unsur-unsur ragam hias tradisional. Varibel ekonomi telah menjadi pembenaran akan model semacam ini. Namun, identitas branding produk terkadang tetap terselipkan. Model keempat adalah mencoba mengembangkan ragam hias berdasarkan riset. Metode semacam ini dilakukan oleh pengrajin dengan skala besar misalnya dengan melakukan riset secara ilmiah terhadap perkembangan atau selera pasar. Produsen tersebut membuat survei dan iklan sekaligus untuk mengetahui dan membentuk persepsi masyarakat akan ragam hias yang diciptakannya. Model keempat adalah mengeksplorasi teknik dan media yang digunakan agar menghasilkan desain yang selalu up to date. Misalnya, menggabungkan bahan-bahan yang dianggap limbah agar menjadi konstruksi yang menarik.

6. Faktor yang Mempengaruhi Pengrajin Melakukan Perubahan Ragam Hias pada Kriya Ukir, Batik, dan Kuningan

Berdasarkan data observasi di lapangan maka ditarik simpulan bahwa faktor-faktor yang mempengaruhi para pengrajin melakukan perubahan ragam hias pada kriya ukir, batik, dan kuningan dapat dikelompokan menjadi faktor internal pengrajin dan faktor eksternal pengrajin. Berikut ini adalah penjelas kedua faktor tersebut:

1. Faktor Internal Pengrajin

Faktor internal pengrajin meliputi ketersedian bahan baku, ekonomi, psikologi atau kepekaan estetik, akses pengrajin yang memiliki mobilitas cukup tinggi, keinginan meningkatkan citra. Ketersediaan bahan baku sebagai material utama kriya tentunya akan semakin memudahkan para pengrajin membuat 
produk-produk yang berkualitas. Namun, penyediaan bahan baku kuningan yaitu tembaga dan kuningan sangat sulit diperoleh atau relatif mahal sehingga membuat pengrajin hanya membuat yang benar-benar fungsional. Akibatnya, mereka jarang melakukan eksplorasi ragam hias. Berbanding terbalik dengan penyediaan bahan baku kriya ukir dan batik yang relatif lebih mudah untuk mendapatkannya.

Ekonomi, sebagian besar pengrajin menjadikan aktivitas pembuatan kriya ukir, batik, dan kuningan merupakan sumber mata pencaharian pokok. Faktor demikian ini, tentu berimplikasi bahwa ragam hias yang diciptakan akan berusaha diselaraskan dengan motif atau ragam hias yang sedang ngetrend di pasar. Psikologi atau kepekaan estetik pengrajin dengan ditunjang naluri berkarya seni akan selalu menghadirkan bentuk yang berbeda dari sebelumnya dengan corak yang unik dan kesan berbeda. Akses pengrajin yang memiliki mobilitas cukup tinggi dapat membentuk terjadinya perubahan struktur, fungsi dan sistem sosial dalam masyarakat. Para kriyawan juga sekarang lebih memiliki akses komunikasi maupun transportasi antar satu daerah ke daerah lain dan antar negara ke negara lain. Pengetahuan yang dimiliki akan ragam hias di luar negeri akan dibawa ke dalam negeri untuk diterapkan dalam karya produksinya. Keinginan pengrajin untuk meningkatkan citra juga sebagai bagian dari strategi pengrajin dalam penciptaan ragam hias yang khas. Dengan konsistensi pembuatan ragam hias yang khas, harapannya citra produk kriya akan mudah dikenal oleh masyarakat luas.
2. Faktor Lingkungan Eksternal,

Faktor lingkungan eksternal meliputi faktor kebijakan politis negara, teknologi yang telah berkembang, sifat pasar dan permintaan, dan kontak dengan budaya luar. Kebijakan politis negara saat ini yang membebaskan bea masuk suatu produk dari luar negeri mengakibatkan persaingan sebuah produk kriya menjadi kompettitif. Situasi demikian menjadikan pengrajin relatif mengupayakan peningkatan kualitas produknya. Salah satunya adalah dengan membuat ragam hias yang variatif. Penggalian ragam hias yang terinsiprasi dari potensi-potensi lokalitas terus dieksploitasi dan dieksplorasi baik secara bentuk maupun teknik.

Teknologi yang telah berkembang diharapkan juga akan menopang dan mampu memenuhi tuntutan produksi. Pergeseran teknik produksi secara manual pada teknologi telah memberikan efisien dan efektifitas tehadap waktu yang digunakan dalam proses produksi sehingga berpengaruh juga terhadap kualitas maupun kuantitas produk yang dihasilkan. Sifat pasar dan permintaan yang terus tumbuh dan fluktuatif mengakibatkan pengrajin terus melakukan eksplorasi ragam hias yang diciptakannya. Sedangkan kriya kuningan, permintaan pasar relatif sepi maka motif ragam hias tidak berkembang semeriah pada kriya batik. Kontak dengan budaya luar menjadikan ragam hias lebih berkembang karena adanya interaksi produsen yang semakin luas sehingga dapat memperluas wawasan produsen. 


\section{Simpulan dan Saran}

Simpulan yang dapat ditarik berdasarkan analisis dan pembahasan adalah sebagai berikut. Pertama, paradigma pengrajin ukir, batik, dan kuningan dalam memahami desain lokalitas dalam konteks globalisasi adalah sangat bersifat fleksible atau dinamis. Kelokalan adalah karakter daerah yang seharusnya dapat menyesuaikan perkembangan, tidak harus bersifat kedaerahan setempat akan tetapi dapat lebih bersifat nusantara. Kedua, model strategi pengembangan ragam hias dilakukan secara intrinsik dan ekstrinsik, meniru ragam hias yang lagi ngetrend, dan menciptakan ragam hias berdasarkan riset. Ketiga, faktor-faktor yang mempengaruhi pengrajin adalah faktor internal pengrajin yang meliputi ketersedian bahan baku, ekonomi, psikologi atau kepekaan estetik, akses pengrajin yang memiliki mobilitas cukup tinggi, keinginan meningkatkan citra dan faktor lingkungan eksternal yang meliputi kebijakan politis negara, teknologi yang telah berkembang, sifat pasar dan permintaan, dan kontak dengan budaya luar.

Beberapa saran yang dapat dikemukakan adalah sebagai berikut. Pertama, perlu dipupuk dan digairahkan bagi para pengrajin untuk dapat menampilkan citra unigue. Kedua, perajin, desainer, akademik, pelaku kebijakan sebaiknya berkoordinasi dalam pengembangan ragam lokalitas yang mampu menembus globalisasi.
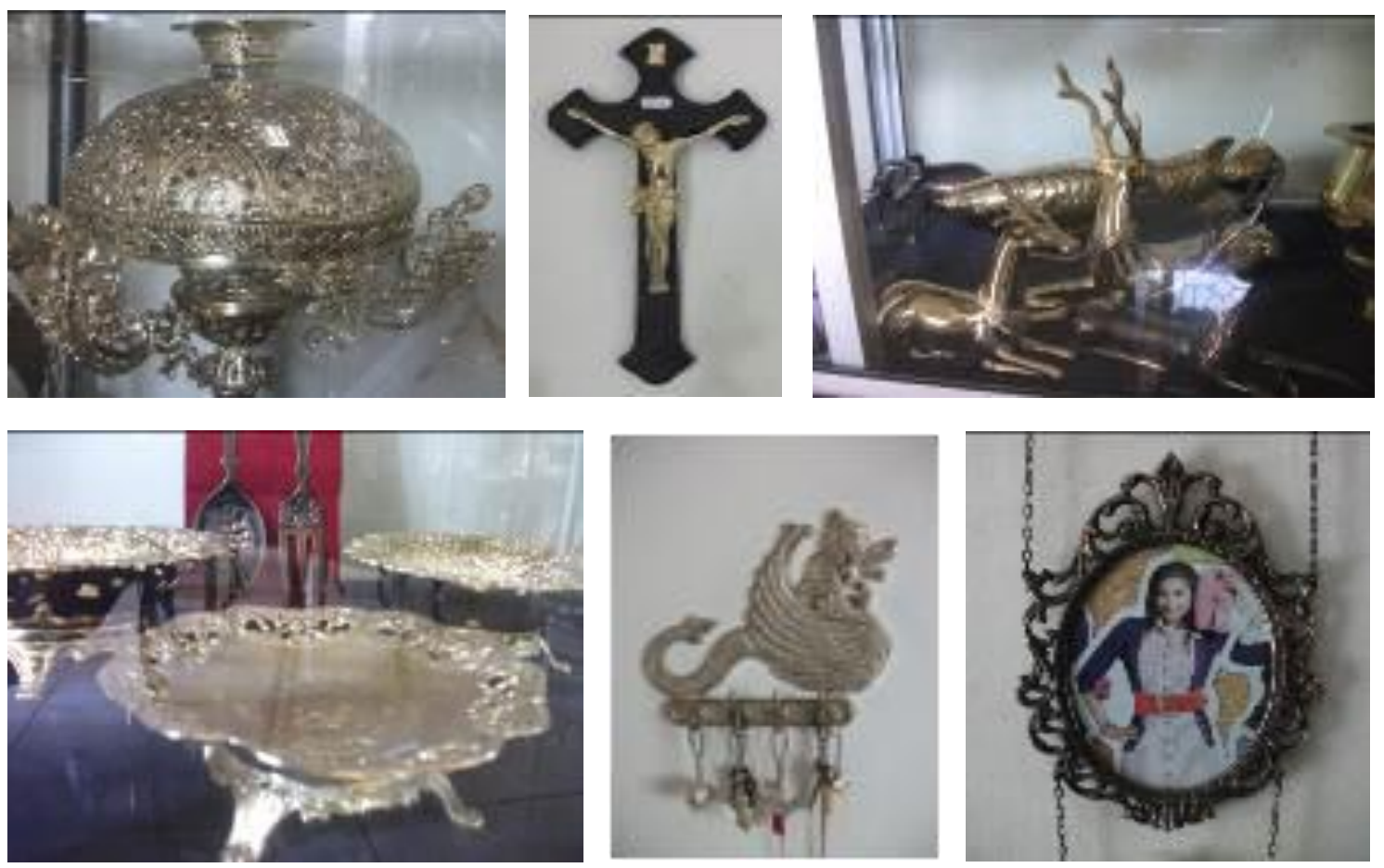

Gbr L. 1. Berbagai bentuk kriya kuningan beserta karakteristik ragam hiasnya baik pada kriya terapan maupun kriya seni (Sumber: Dokumetasi Penulis) 

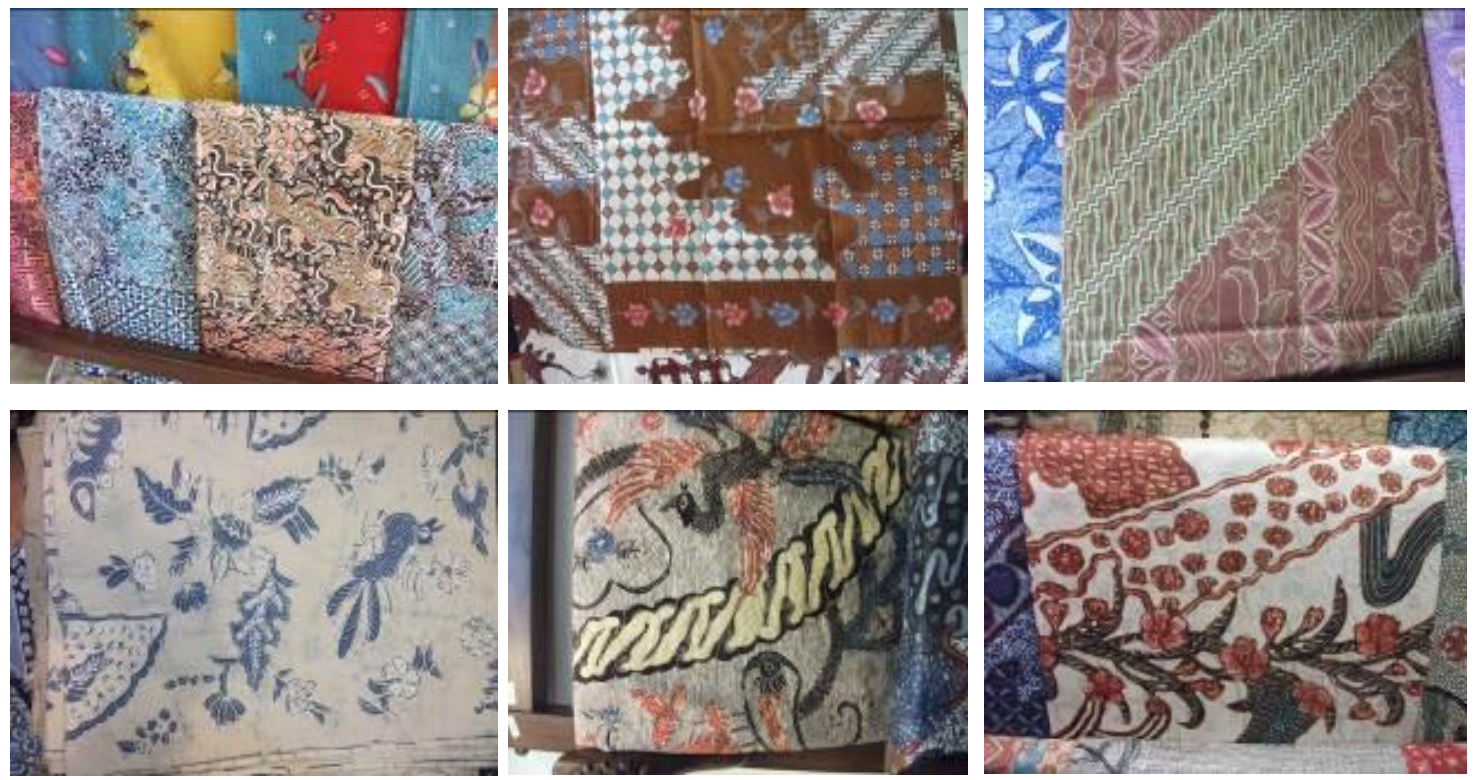

Gbr L. 2. Berbagai ragam hias pada seni batik sangat beragam bentuk motif dan warna yang digunakan. Tema naturalistik tampaknya masih mendominasi dibandingkan tema atau motif lainnya

(Sumber: Dokumetasi Penulis)
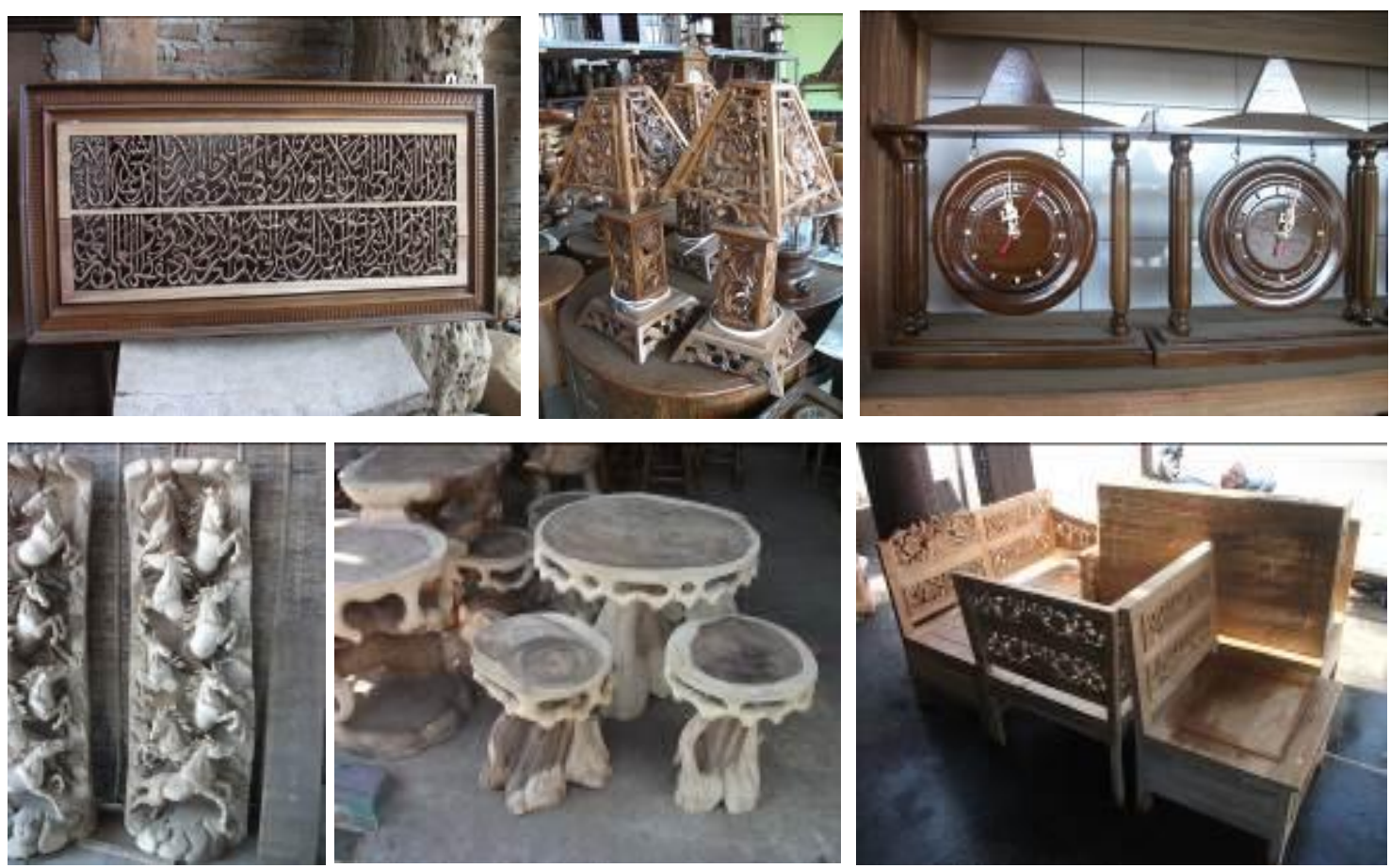

Gbr L. 3. Berbagai ragam hias khas Jepara seperti sulur-suluran tumbuhan juga masih dijumpai pada kriya seni maupun terapan. Namun terdapat pula seni ukir lainnya yang sama sekali tidak mengaplikasikan sebuah ragam hias khas Jepara (Sumber: Dokumetasi Penulis) 


\section{Daftar Pustaka}

Anwar, Kesuma. 2007. "Motif Batik Pekalongan dan Perkembangannya". Skripsi. Jurusan Seni Rupa Fakultas Bahasa dan Seni UNNES.

Franklin H. Gootshall, 1937. How to Design and Construct Periode Furniture. New York.

Fortain, Jan. 1972. Kesenian Indonesia Purba. New York: Asia House Gallery.

Gustami. 2000. Seni Kerajinan Mebel Ukir Jepara: Kajian Estetika Melalui Pendekatan Multidisiplin. Yogyakarta: Kanisius

Ham, Ong Hok. 2002. Dari Soal Priyayi Sampai Nyi Blorong: Refleksi Historis Nusantara.

Jakarta: Penerbit Buku Kompas.

Holt, Claire. 1957. Art in Indonesia. New York: Corner University Press Itacha.

Herusatoto, Budiono.2000. Simbolisme dalam Budaya Jawa. Yogyakarta: Hanindita.

Koswara, Aji. 1996. Ukiran Jepara. Bandung: Tesis ITB

Koentjaraningrat. 1994. Kebudayaan Jawa. Jakarta: Balai Pustaka

Lombart, Denys. 2000. Nusa Jawa Silang Budaya, Bagian Satu: Batas-batas Pembaratan. Jakarta: Gramedia Pustaka Utama

Poerwodarminto. 1939. Baoesastra Djawa. Batavia: JB. Wolters Uitgevers

Read, Herbert. 1956. Art and Industry. London: Faber and Faber Ltd, h.40
Rohidi, T.R. 2000. Kesenian dalam Pendekatan Kebudayaan. Bandung : STISI.

Sachari, Agus. 2005. Metodologi Penelitian Budaya Rupa. Jakarta: Erlangga.

Spradley, J. P. 1997. Metode Etnografi. Yogyakarta: PT Tiara Wacana Yogyakarta.

Sukijo, Sudarmono. 1979. Pengetahuan Teknologi Kerajinan Ukir Kayu. Jakarta: Depdikbud

Sunarko, Keny. 1981. Mebel Kuno di Jawa. Bandung: Skripsi ITB

Suseno, Frans Magnis. 1996. Etika Jawa, sebuah Analisa Falsafi Tentang Kebijaksanaan Hidup. Jakarta: Gramedia

Solichin, Nanik S. 1975. "Tinjauan Seni Ornamen pada Bangunan Tradisional. Indonesia". Skripsi. Bandung: ITB

Sutjipto, Djoko. 1995. "Ragam Hias Tradisional dan Penerapannya dalam Desain". Tesis Bandung: ITB Triyanto.2012. " Seni Ukir Belakang Gunung Desa Mulyoharjo: Varian dalam Khazanah Tradisi Budaya Seni Ukir di Jepara". Laporan Penelitian Dasar. Jurusan Seni Rupa Fakultas Bahasa dan Seni Universitas Negeri Semarang.

Thohir, Mudjahirin. 1999. Wacana Masyarakat dan Kebudayaan Jawa Pesisir. Semarang: Bendera

Widagdo. 2006. "Penelitian Bidang Seni Rupa" dalam Jaringan Makna Tradisi Hingga Kontemporer. Yogyakarta: BP ISI 
36] CORAK Jurnal Seni Kriya Vol. 2 No.1, Nopember-April 2013

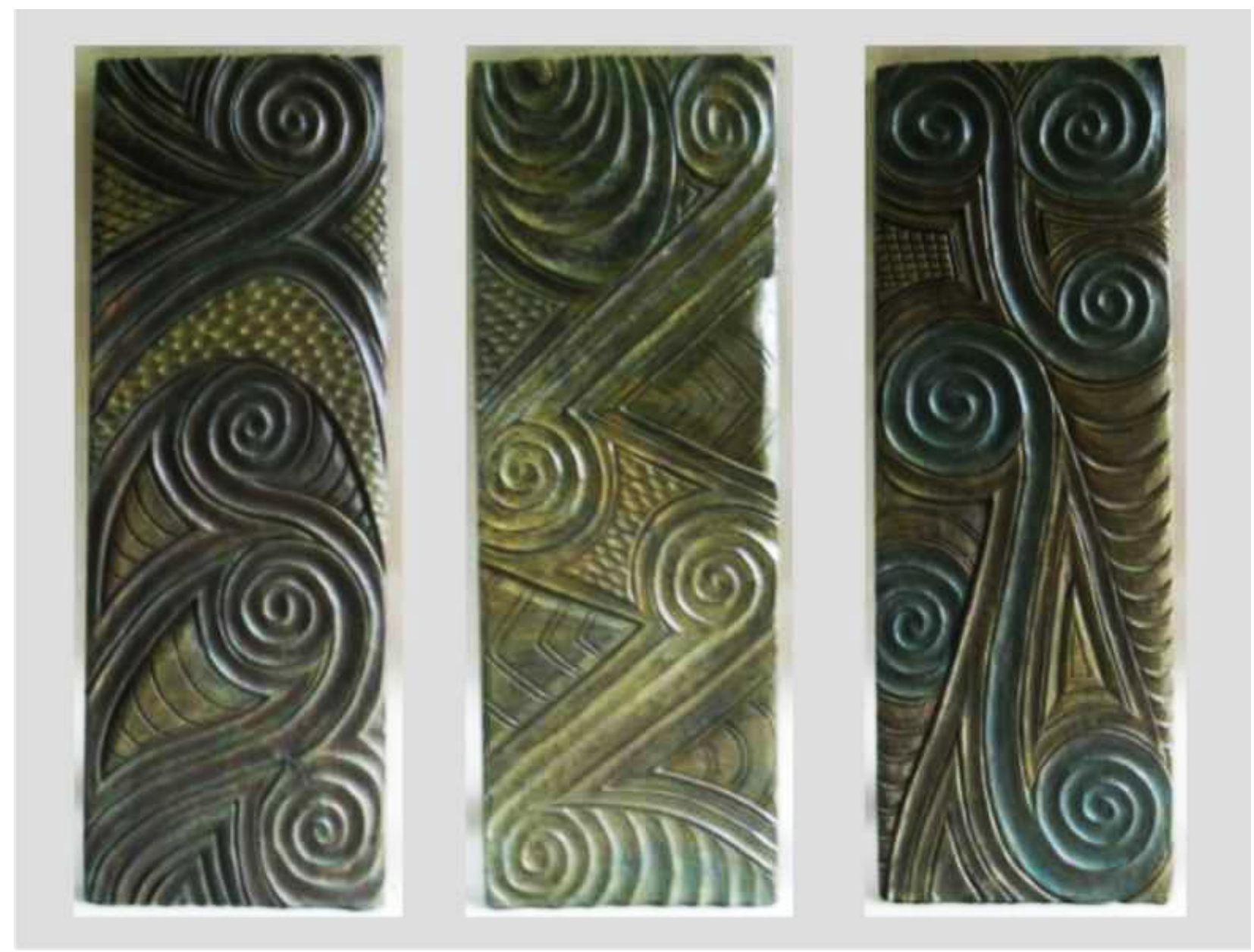

Herry PH.

Hiasan Dinding Kontempo

Kayu Munggur

$100 \times 40 \times 3 \mathrm{~cm}$

2013 